\title{
Factors that Determine House Price Index in Malaysia
}

\author{
Muhammad Faiz Abdul Rahman ${ }^{1}$, Abdul Rahim Ridzuan ${ }^{2}$ \\ ${ }^{1}$ Institute of Postgraduate Studies, Universiti Teknologi MARA, Melaka Campus, ${ }^{1}$ E-mail: Aimanryhan97@gmail.com \\ ${ }^{2}$ Faculty of Business and Management, Universiti Teknologi MARA, Melaka Campus, ${ }^{2}$ E-mail: \\ Rahim670@staf.uitm.edu.my
}

\begin{tabular}{|c|c|c|}
\hline Abstract & \multicolumn{2}{|c|}{$\begin{array}{l}\text { Housing is a major industry where price mechanisms or market regulations are applied for efficiency, and } \\
\text { house provision is controlled by governments. Malaysia is one of the countries that are facing an upward } \\
\text { trend in demand for housing, and the increase in housing prices has become worrying. This paper } \\
\text { investigated the impact of macroeconomic variables in the house price index in Malaysia from the period } \\
1988 \text { until } 2017 \text { by annually. The selected macroeconomics variables for this study are gross domestic } \\
\text { product, consumer price index, base lending rate, and money supply. Autoregressive Distributed Lag (ARDL) } \\
\text { estimation was used to investigate the short-run and long-run elasticities of the proposed econometric model } \\
\text { based on the selected macroeconomic variable mention above. The results from the Augmented Dickey-Fuller } \\
\text { and Phillips-Perron tests of stationarity indicated that all the variables were non-stationary at the level I (o) } \\
\text { but stationary at the first difference I (1). The long-run elasticities showed that gross domestic product and } \\
\text { base lending rate is significant and positively influenced house price index in Malaysia. Consumer price index } \\
\text { and money supply have a negative impact on house price index in the long run. }\end{array}$} \\
\hline Key words & \multicolumn{2}{|c|}{ House Price Index, ARDL, Gross Domestic Product, Consumer Price Index, Base Lending Rate, Money Supply } \\
\hline Received: & 12 Apr 2020 & (C) The Authors 2020 \\
\hline Revised: & 10 May 2020 & Published by Human Resource Management Academic Research Society (www.hrmars.com) \\
\hline ublished Online: & 14 May 2020 & $\begin{array}{l}\text { This article is published under the Creative Commons Attribution (CC BY } 4.0 \text { ) license. Anyone may } \\
\text { reproduce, distribute, translate and create derivative works of this article (for both commercial and } \\
\text { non-commercial purposes), subject to full attribution to the original publication and authors. The full } \\
\text { terms of this license may be seen at: http://creativecommons.org/licences/by/4.0/legalcode }\end{array}$ \\
\hline
\end{tabular}

\section{Introduction}

Malaysia is facing rapid economic development throughout this past decade, which has become the major factor for the increase in demand for residential housing, particularly in urban areas. As a house is the most basic needs of humans, the rising price level over the year has affected the affordability of households in Malaysia to own the houses. The study reveals the increasing number of housing prices causes the uncertainty of the investors, especially in the long run.

Opportunities to understand the dynamics of the real estate market are provided by the advancement of technology by accurately measuring the price indicator of real estate to monitor the changes in the price from time to time. The prices of houses have appreciated dramatically, whether in the urban or rural areas. As such, a house price index is widely used as real estate price indicators. The house price index is critical to the housing market because it is unpredictable and lead to the volatility of the real estate market. Moreover, it is the most important factor for the household to decide on buying or selling real estate.

In late 2007, the United States experienced a sub-prime crisis affected by the global financial crisis. It was due to financial deregulation, which had a significant impact on the rest of the world. Malaysia's investor and policymaker should guide the housing price to identify structural changes and economic fluctuation. Drastic price appreciation of housing prices in Malaysia can be seen in Figure 1.0, from an index 
of 93.4 to an index of 213.1 in 2014. This shows a steady increase in the housing price index in Malaysia since 1999, and the price index is double when it reached the year 2014.

Figure 1. Housing Price Index in Malaysia, 1999 - 2014

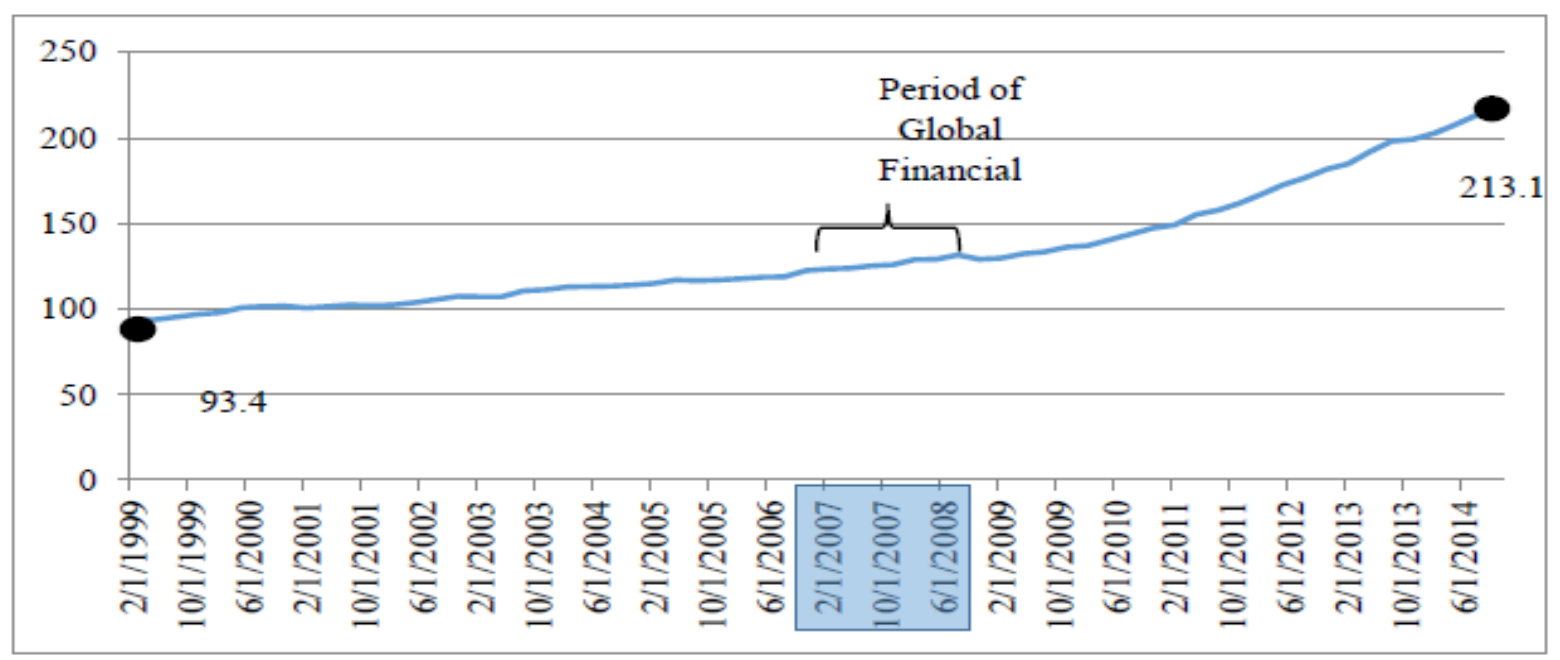

\section{Literature review}

House price index gives a reflection of the difference in prices in the housing sector. It also can be used as a guidance for rent, debts, and the risk assessment for housing loans that includes the MortgageBacked Securities (MBS). The housing market is a strong positive relationship with the growth of the economy based on the housing price index (Afiqah et al., 2014). Malaysian had used the term Malaysian House Price Index (MHPI) to measure the average housing price, and this was published by the National Property Information Centre (NAPIC) quarterly and it is created by the Valuation and Property Services Department (VPSD). Based on NAPIC, base year changes reflect changes in house prices according to buyer's preference and the emergency new trends in the marketplace and to control the housing price in Malaysia. MHPI is also used in property development to create a national economic policy.

On the GDP basis, Qing (2010) stated that an increase in investment would lead to an increase in gross domestic product. It shows the relationship that property investment is part of the GDP. Ong (2013) found that GDP is significantly and positively related to the MHPI. According to Chioma (2009), the increase in consumption expenditure also leads to an increase in GDP, which also leads to an increase in housing prices. Correlation between housing prices and GDP was statistically significant (Grum \& Govekar, 2016). Other studies, such as Zhu (2006) shown that the housing price and housing market demonstrate a very significant positive correlation with the GDP rate in Asia. Some scholars discovered housing prices and GDP rates have a negative influence. (Zandi et al., 2015) indicating that housing prices had a negative impact on the GDP rate. Based on Dougherty \& Order (1982) and Harris (1989), the use of inflation rates as a variable in the study of house prices has been studied since the 1970s, with Consumer Price Index as the basis of measurement of inflation rates. However, based on Zandi et al. (2015), the housing price indicated no correlation by inflation in Malaysia due to the result which inflation rate has very high F-value. Some studies also found there is an insignificant effect of inflation on housing prices (Tze, 2013; Tan, 2011). Madsen (2012) also claimed that the negative relationship of inflation on real estate prices. Most of the items, including daily necessities, even the building materials, would rise during inflation and affect house prices (Zhu, 2004). Zou \& Chau (2015) also found out that in the long run, inflation would positively and slightly impact real estate prices. Moreover, in the short run, changes in inflation are significantly positive and impressively impact real estate prices.

Base Lending Rate (BLR), or lending rate and mortgage rate in a layman term, is defined as the charges on loan. Any changes in interest rates and income will immediately affect the housing price in the market, not only in Malaysia but in every country. The research by Shi et al. (2015) stated that there is a positive relationship between the interest rate and the price of the house. This statement is also supported by Tse et al. (2015). Discounted expected, a future stream of cash flow could determine the price of the 
house by encouraging current and future economic activity, which is by lowering lending rates. It also means that commercial banks increase the availability of credit. According to Bank Negara Malaysia (2012), the fall in demand in citizens buying a house is a consequence of increasing in BLR and an increase in the price of the house. The relationship between housing price and household borrowing is two-sided, in which housing prices may significantly influence household borrowing through the various wealth effect. When the housing finance interest is low, citizens will be enabled to make some investment, such as buying or renovate the house. The traditional monetarist view of the connection between house prices and money is based on the system for optimum portfolio adjustment. This translates to an increase in the price of a broad range of assets and a decrease in interest rates. As such, from a theoretical point of view, an increase in the money supply will lead to increase in house prices. Adalid \& Detken (2016) analyzed the effect of broad money growth on house prices in several industrialized countries. They found a significant relationship between broad money growth and house prices. This relationship was strongest during periods of price booms. Ball (2016) examined how the relationship between urbanization processes and economic growth will affect housing prices, which is the money supply has a lagged effect on current housing returns, implying a possible refutation of market efficiency. Monetary policy and nominal interest rates play an important role in the determination of real estate prices, as well as money shocks by generating remarkably very volatile housing investors.

Table 1. Summary of Empirical Literature

\begin{tabular}{|c|c|c|c|}
\hline \multirow{2}{*}{ Studies of } & \multirow{2}{*}{ Sample and period } & Method & \multirow{2}{*}{ Explanatory variable } \\
\hline & & Time Series Cross country/panel & \\
\hline Ong (2013) & $\begin{array}{c}\text { Malaysia } \\
1996-2015\end{array}$ & OLS & GDP positive toward HPI \\
\hline Grum and Govekar (2016) & $\begin{array}{c}\text { Malaysia } \\
1990-2001\end{array}$ & OLS & GDP positive toward HPI \\
\hline Zandi et al. (2015) & $\begin{array}{c}\text { Malaysia } \\
2009-2016\end{array}$ & OLS & GDP positive toward HPI \\
\hline Zandi et al. (2015) & $\begin{array}{c}\text { Malaysia } \\
2009-2016\end{array}$ & OLS & CPI positive toward HPI \\
\hline Ong (2013) & $\begin{array}{c}\text { Malaysia } \\
1996-2015\end{array}$ & OLS & CPI positive toward HPI \\
\hline Roger (2001) & $\begin{array}{c}\text { Europe } \\
1995-2010\end{array}$ & ARDL & $\mathrm{CPI}$ positive toward $\mathrm{HPI}$ \\
\hline Tse et al. (2014) & $\begin{array}{c}\text { Malaysia } \\
1998-2012\end{array}$ & OLS & BLR positive toward $\mathrm{HPI}$ \\
\hline Zhu (2006) & $\begin{array}{c}\text { India } \\
1994-2006\end{array}$ & OLS & BLR positive toward HPI \\
\hline Barakova (2003) & $\begin{array}{c}\text { Europe } \\
1996-2006\end{array}$ & OLS & BLR positive toward HPI \\
\hline Greiber and Setzer (2007) & $\begin{array}{l}\text { United State } \\
1990-2014\end{array}$ & ARDL & M3 positive toward HPI \\
\hline Kim (1993) & $\begin{array}{c}\text { Korea } \\
1989-2001\end{array}$ & OLS & M3 positive toward HPI \\
\hline Dennis and Yang (2008) & $\begin{array}{c}\text { Taiwan } \\
1999-2009\end{array}$ & OLS & M3 positive toward $\mathrm{HPI}$ \\
\hline
\end{tabular}

\section{Methodology of research}

In this research, the following model was adopted as follows:

$\mathrm{HPI}=\mathrm{f}(\mathrm{GDP}, \mathrm{CPI}, \mathrm{BLR}, \mathrm{M} 3)$

Where:

$\mathrm{HPI}=$ House Price Index; GDP = Gross Domestic Product; $\mathrm{CPI}=$ Consumer Price Index

$\mathrm{BLR}=$ Base Lending Rate; M3 = Money Supply.

To test the stationarity of each variable, the log form of the variables was used. Log transformation can reduce the problem of heteroscedasticity because it compresses the scale in which the variables are 
measured, thereby reducing a tenfold difference between two values to twofold difference (Gujarati, 1995).

$$
L N H P I_{i t}=\alpha_{0}+\beta_{1} L N G D P_{i t}+\beta_{2} L N C P I_{i t}+\beta_{3} L N B L R_{i t}+\beta_{4} L N M 3_{i t}+\varepsilon_{t}
$$

The short and long-run dynamic relationships between the house price index and other variables are estimated by using the newly proposed ARDL bound testing approach, which was initially introduced by Pesaran et al. (1997). ARDL has numerous advantages. Firstly, unlike the widest method used for testing cointegration, the ARDL approach can be applied regardless of the stationarity properties of the variables in the samples and allows for inferences on long-run estimates, which is not possible under the alternative cointegration procedures. In other words, this procedure can be applied irrespective of whether the series is I(0), I(1), or fractionally integrated (Pesaran et al., 1997); and Bahmani-Oskooee \& Ng, 2002), thus avoid problems resulting from non-stationary time series data (Laurenceson \& Chai, 2003). Secondly, the ARDL model takes sufficient numbers of lags to capture the data generating process in a general-to-specific modelling framework (Laurenceson \& Chai, 2003). It estimates $(p+1) k$ number of regressions to obtain optimal lag-length for each variable, where $p$ is the maximum lag to be used, $k$ is the number of variables in the equation. Finally, the ARDL approach provides robust results for a smaller sample size of cointegration analysis.

\subsection{ARDL Model}

The model was transformed into Bound Testing approach

$$
\begin{aligned}
\triangle L N H P I= & \beta_{0}+\theta_{0} L_{N G D P_{t-1}}+\theta_{1} L_{N C P I_{t-1}}+\theta_{2} L_{N}{ }^{2} L R_{t-1}+\theta_{3} L_{N M 3_{t-1}}+\sum_{i=1}^{a} \beta_{i} \Delta L N G D P_{t-i}+ \\
& \sum_{i=0}^{b} \gamma_{i} \Delta L N C P I_{t-i}+\sum_{i=0}^{c} \delta_{i} \Delta L N B L R_{t-i}+\sum_{i=0}^{d} \lambda_{i} \Delta L N M 3_{t-i}+v_{t}
\end{aligned}
$$

Where $\Delta$ is the first difference operator and $v t$ is a white-noise disturbance term. The final model represented in equation (3.0) above can also be viewed as an ARDL of order, ( $p q r s t u)$. The model indicates house price index performance (HPI) tends to be influenced and explained by its past values, so it involves other disturbance or shocks. From the estimation of UECM, the long-run elasticities are the coefficient of the one lagged explanatory variables (multiplied by a negative sign) divided by the coefficient of the one lagged dependent variable. The short-run effects are captured by the coefficient of the first differenced variables. The null of no cointegration in the long-run relationship is defined by:

$H 0: \theta 0=\theta 1=\theta 2=\theta 3=\theta 4=\theta 5=0$ (there is no long-run relationship)

Against the alternative hypothesis

$H 1$ : $\theta 0 \neq \theta 1 \neq \theta 2 \neq \theta 3 \neq \theta 4 \neq \theta 5 \neq 0$ (there is a long-run relationship exists)

However, the asymptotic distribution of this F-statistics is non-standard irrespective of whether the variables are I(0) or I(1). For a small sample size study ranging from 30 to 80 observations, Narayan (2004) has tabulated two sets of appropriate critical values. One set assumes all variables are I(1), and another assumes that they are all I(0). If the F-statistic falls below the bound level, the null hypothesis cannot be rejected. On the other hand, if the F-statistic lies exceed the upper bound level, the null hypothesis is rejected, which indicated the existence of cointegration. If, however, it falls within the band, the result is inconclusive.

\subsection{Source of data}

All independent variables are acquired straight from world bank information, while NAPIC obtains the dependent variable ( $\mathrm{HPI}$ ) and is analyzed based on time-series data. The sample size includes 30 years of annual data, covering a total of 30 observations for both dependent and independent variables from 1988 to 2017.

\section{Empirical results and discussions}

The analysis begins with testing the unit root of every variable for Malaysia. Unit root tests such as Dickey-Fuller (DF)/Augmented Dickey-Fuller (ADF), and the Phillip Perron (PP) test are carried out to determine in performance house price index in Malaysia. 
Based on Malaysia's house price index model, it is found that LNHPI, LNGDP, LNCPI, LNM3 AND LNBLR at level, I (0), ADF unit root test is not significant at both level no trend and with the trend. At first difference I (1) all the variables are stationary at $1 \%$ significant level for both no trend and with the trend. The unit root test was tested by a more powerful test, which is Phillip-Perron (PP) test. At the level I (0), all the variables are not significant for both no trend and with trend except for LNGDP and LNCPI are stationary at $1 \%$ and $5 \%$ significant level for no trend. LNHPI, LNGDP, LNCPI, LNM3, AND LNBLR are stationary at a $1 \%$ significant level as it is run by using the first difference, I (1).

Table 2. ADF and PP Unit Root Test for Model of Housing Price Index

\begin{tabular}{|c|c|c|c|c|}
\hline \multirow{2}{*}{$\begin{array}{l}\text { Level } \\
\text { I (0) }\end{array}$} & \multicolumn{2}{|c|}{ ADF Unit Root } & \multicolumn{2}{|c|}{ PP Unit Root } \\
\hline & Intercept & Intercept and Trend & Intercept & Intercept and Trend \\
\hline LNHPI & $-1.668(0)$ & $-1.774(0)$ & $-1.668(0)$ & $-1.774(0)$ \\
\hline LNGDP & $-2.022(0)$ & $-2.470(0)$ & $-3.997(13) * * *$ & $-2.479(8)$ \\
\hline LNCPI & $-2.393(0)$ & $-1.784(0)$ & $-3.665(12) * *$ & $-1.748(7)$ \\
\hline LNM3 & $-0.104(0)$ & $-1.748(0)$ & $-0.011(3)$ & $-1.748(0)$ \\
\hline LNBLR & $-1.928(0)$ & $-2.460(0)$ & $-1.894(9)$ & $-2.175(11)$ \\
\hline \multirow{2}{*}{$\begin{array}{c}\text { First difference } \\
\text { I (1) }\end{array}$} & \multicolumn{2}{|c|}{ ADF Unit Root } & \multicolumn{2}{|c|}{ PP Unit Root } \\
\hline & Intercept & Intercept and Trend & Intercept & Intercept and Trend \\
\hline LNHPI & $-4.702(0) * * *$ & $-4.620(0) * * *$ & $-4.695(2) * * *$ & $-4.595(3) * * *$ \\
\hline LNGDP & $-5.555(0) * * *$ & $-6.083(0) * * *$ & $-5.559(1) * * *$ & $-6.816(7) * * *$ \\
\hline LNCPI & $-4.634(0) * * *$ & $-5.042(0) * * *$ & $-4.632(1) * * *$ & $-5.056(7) * * *$ \\
\hline LNM3 & $-5.235(0) * * *$ & $-5.220(0) * * *$ & $-5.240(3) * * *$ & $-5.336(5) * * *$ \\
\hline LNBLR & $-4.693(0) * * *$ & $-4.608(0) * * *$ & $-6.778(27) * * *$ & $-6.544(27) * * *$ \\
\hline
\end{tabular}

Note: $1 . * * *, * *$ and $*$ are $1 \%, 5 \%$ and $10 \%$ of significant levels, respectively. 2 . The optimal lag length is selected automatically using the Schwarz Info Criteria (SIC) for the ADF test, and the bandwidth had been selected by using the Newey-West method for the PP unit root test.

\subsection{Detecting the Long-Run Relationship}

This tested model must pass the detection of long-run cointegration before proceeding to the short and long-run elasticities. The variables had been tested by using the ARDL cointegration, and the result of this analysis is displayed in Table 3 . As a result, the maximum lag was set equal to $(4,3)$, and the optimum lag order was $(4,2,3,0,2)$ obtained by Akaike Information Criteria (AIC). The critical value must be compared with the F-statistic, which is if the F-statistics below the bound level, the null hypothesis cannot be rejected. Still, if the F-statistic is greater than the upper bound level, the null hypothesis is rejected, and it shows signifying the existence of cointegration. The finding in Table 3 shows that F-statistics are greater than upper (1) critical bound at the $1 \%, 5 \%$, and $10 \%$ level of significance. This shows that rejection of the null hypothesis of no cointegration considering LNGDP, LNCPI, LNM3, and LNBLR is a dependent variable. Based on the result, the long-run exists in the variables in this model.

The null hypothesis of no cointegration for housing price index $(10.868>5.06)$ is rejected at $1 \%$ significant level, given that the F-statistic value was greater than the upper bound critical value and shows the long-run relationship exist between the variables.

Table 3. F-statistic for Testing the Existence of Long Run Equation

\begin{tabular}{l|ccc}
\hline \multicolumn{1}{c}{ Model } & Max Lag & Lag order & F statistics \\
\hline LNHPI=F(LNGDP, LNCPI, LNM3, LNBLR) & $(4,3)$ & $(4,2,3,0,2))$ & $10.868^{* * *}$ \\
\hline Critical Values for F stat & & Lower I(0) & Upper (1) \\
\hline $10 \%$ & & 2.45 & 3.52 \\
$5 \%$ & & 2.86 & 4.01 \\
$1 \%$ & & 3.74 & 5.06 \\
\hline
\end{tabular}

Note: 1. \# the critical values are based on Pesaran et al. (2001), case III: unrestricted intercept, and no trend. $2 . \mathrm{k}$ is a number of variables, and it is equivalent to 5 . 3. ${ }^{*}, * *$, and $* * *$ represent $10 \%, 5 \%$, and $1 \%$ level of significance, respectively. 


\subsection{Diagnostic checking}

Before the result was analysed, it is important to check the robustness of the model by adopting several diagnostic tests such as Breusch-Godfrey serial correlation LM test, ARCH test, Jacque-Bera normality test, and Ramsey RESET specification test. All tests showed that the model has the desired econometric properties. Namely, it has a correct functional form, and the model's residuals are serially uncorrelated and homoscedastic given that the probability value of the t-test is all above than $10 \%$ significant.

Table 4. Diagnostic Tests for Model of Housing Price Index

\begin{tabular}{|l|c|c|c|c|}
\hline \multirow{2}{*}{ Model } & $(\mathrm{A})$ & $(\mathrm{B})$ & $(\mathrm{C})$ & $(\mathrm{D})$ \\
\cline { 2 - 5 } & $\begin{array}{c}\text { Serial Correlation } \\
{[p \text {-value] }}\end{array}$ & $\begin{array}{c}\text { Functional Form } \\
{[p \text {-value] }}\end{array}$ & $\begin{array}{c}\text { Normality } \\
\text { [p-value] }\end{array}$ & $\begin{array}{c}\text { Heteroscedasticity } \\
\text { [p-value] }\end{array}$ \\
\hline LNHPI=F (LNGDP, LNCPI, & 1.440 & 2.70 & 1.173 & 0.666 \\
LNM3, LNBLR) & $(0.29)$ & $(0.14)$ & $(0.56)$ & $(0.77)$ \\
\hline
\end{tabular}

Note: $1{ }^{* *}$ represent $5 \%$ significant levels. 2 . The diagnostic test performed as follows A. Lagrange multiplier test for residual serial correlation; B. Ramsey's RESET test using the square of the fitted values; C. Based on a test of skewness kurtosis of residuals; D. Based on the regression of squared fitted values. 2.

Additionally, CUSUM AND CUSUMSQ were applied in this research to examine the reliability of the low output run and the long run. Pesaran et al. $(2000,2001)$ that both statistics are significant in examine for stability if the parameter in such kind of model. The stability of the model was supported because the plots of both CUSUM and CUSUMSQ fall inside the critical bound of the significant level at 5\%. Figure 2 shows the plots of CUSUM, and Figure 3 shows the plot of CUSUMSQ tests. Both graphs are stable because the blue line is inside the dotted red line and significant at $5 \%$ significant level. This shows that the model is stable in the selected time series.

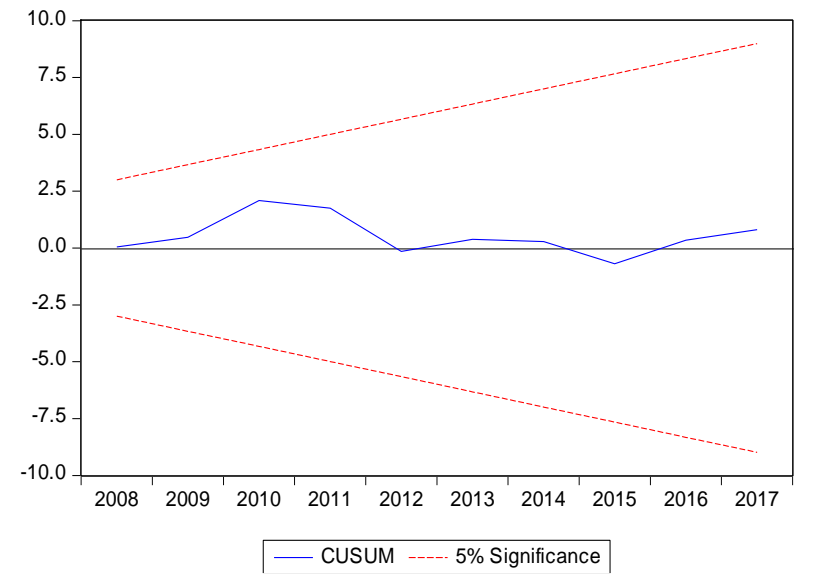

Figure 2. Plot of CUSUM test

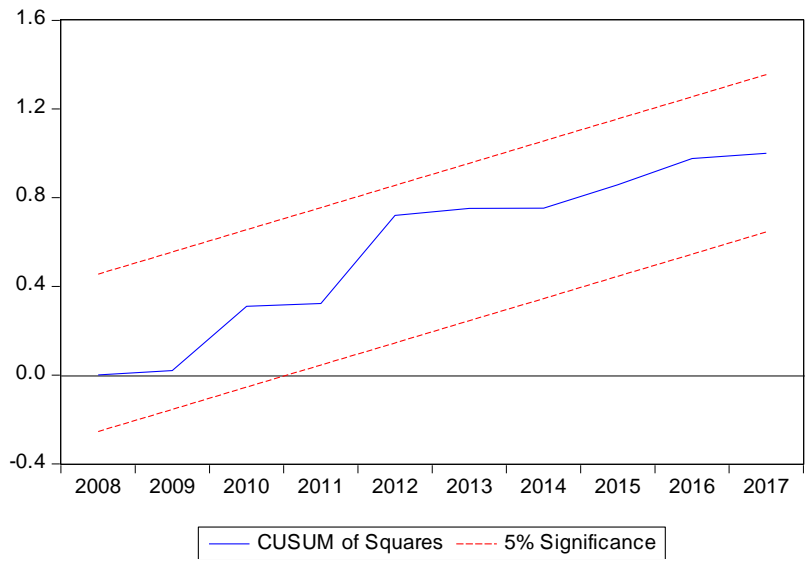

Figure 3: Plot of CUSUMSQ test

Note: 1 . The straight lines represent critical bounds at $5 \%$ significant level

\subsection{Short Run Dynamic and Long-Run Elasticities}

After detecting the long-run relationship for Malaysia, both short-run and long-run model were estimated from equation (3), and the maximum order of lag chosen was four as suggested by Pesaran, Shin, and Smith (2001). From this, the lag length that minimizes Schwarz Bayesian criterion is selected. The ARDL lag order detected for Malaysia is 4, 2, 3, 2, 0.

The short-run elasticities explanation is only based on zero lag. In the short run, the LNGDP shows a positive relationship and significant with LNHPI in Malaysia. Next, it is found that LNCPI also had a significant and positive relationship and significant with LNHPI in Malaysia. Furthermore, this country also shows a significant and positive relationship between LNBLR and LNHPI. Based on the last tested variables, LNM3 had a significant and negative relationship with LNHPI in Malaysia. 
Table 5. Short-run ARDL Estimates

\begin{tabular}{|c|c|c|c|c|}
\hline \multicolumn{5}{|c|}{ Dependent Variable $=$ LNHPI } \\
\hline \multicolumn{5}{|c|}{ Selected Model: ARDL $(4,2,3,2,0)$} \\
\hline Variable & Coefficient & Std. error & t-statistic & Prob. \\
\hline $\mathrm{D}(\mathrm{LNHPI}(-1))$ & 0.532 & 0.231 & 2.301 & 0.044 \\
\hline $\mathrm{D}(\mathrm{LNHPI}(-2))$ & 0.336 & 0.111 & 3.033 & 0.013 \\
\hline $\mathrm{D}(\mathrm{LNHPI}(-3))$ & -0.348 & 0.100 & -3.478 & 0.006 \\
\hline $\mathrm{D}(\mathrm{LNGDP})$ & 1.328 & 0.381 & 3.486 & 0.006 \\
\hline$D(\operatorname{LNGDP}(-1))$ & 3.051 & 0.339 & 9.010 & 0.000 \\
\hline $\mathrm{D}(\mathrm{LNCPI})$ & 0.336 & 0.567 & 0.593 & 0.566 \\
\hline $\mathrm{D}(\mathrm{LNCPI}(-1))$ & -2.322 & 0.654 & -3.552 & 0.005 \\
\hline $\mathrm{D}(\mathrm{LNCPI}(-2))$ & 3.320 & 0.594 & 5.586 & 0.000 \\
\hline $\mathrm{D}(\mathrm{LNBLR})$ & 0.866 & 0.187 & 4.626 & 0.000 \\
\hline $\mathrm{D}(\mathrm{LNBLR}(-1))$ & -0.879 & 0.278 & -3.166 & 0.010 \\
\hline $\mathrm{D}(\mathrm{LNM} 3)$ & -0.004 & 0.030 & -0.121 & 0.906 \\
\hline CointEq(-1) & -0.716 & 0.206 & -3.470 & 0.006 \\
\hline
\end{tabular}

Note: $1 .{ }^{* *}, * *$ and $*$ are $1 \%, 5 \%$ and $10 \%$ of significant levels, respectively.

The estimated lagged error correction term (ECT) in ARDL regression for Malaysia shows negative and statistically significant, which is necessary for model stability. The value of coefficient demonstrates the speed of adjustment for the variables to meet in the long run, which means the higher the value, the higher the speed of adjustment. Based on Table 5, the highest speed of adjustment, also known as ECT, is -0.716 , which means more than $71.6 \%$ of the adjustment are completed in a year for Malaysia country due to the short-run adjustment that is rapid.

Table 6 present the long-run elasticities. The table shows the empirical verdicts of the long-run relationship between the regressors of the proposed ARDL model $(4,2,3,2,0)$. There was a sign at standard significant ( $1 \%$ significant level), and a positive sign detected between gross domestic product (LNGDP) and housing price index (LNHPI) in Malaysia. 1\% increase in LNGDP, LNHPI increased by $0.525 \%$. Ong (2013) found that GDP is significant and positively related to the MHPI. According to Chioma (2009), The increase in consumption expenditure also leads to an increase in GDP, which also leads to an increase in housing prices. It can be evaluated by the consumption expenditure and economic growth.

Positive sign and shows a $1 \%$ significant level detected between the base lending rate (LNBLR) and house price index (LNHPI) in Malaysia. 1\% increase in LNBLR, LNHPI increased by1.605\%. The research was done by Shi, Jou and Tripe in (2015) stated that there is a positive relationship between the interest rate and the price of the house and supported by the Tse, Rodgers, and Niklewski in (2015). The consequence is, households will want to borrow more if they found that they can earn more securities by the instructors in the house. To make things simple, the household will only borrow depending on the amount of their securities' net worth. Because housing's securities value is quite large, a rise in housing wealth opens a household's borrowing limitations.

Table 6. Long-run ARDL Estimates

\begin{tabular}{|c|c|c|c|c|}
\hline \multicolumn{5}{|c|}{ Dependent Variable = LNHPI } \\
\hline \multicolumn{5}{|c|}{ Selected Model: ARDL $(4,2,3,2,0)$} \\
\hline Variable & Coefficient & Std. Error & t-Statistic & Prob. \\
\hline LNGDP & $0.525^{* * *}$ & 0.231 & 2.273 & 0.046 \\
\hline LNCPI & 0.104 & 0.703 & 0.147 & 0.886 \\
\hline LNBLR & $1.605^{* * *}$ & 0.304 & 5.281 & 0.000 \\
\hline LNM3 & -0.005 & 0.041 & -0.121 & 0.906 \\
\hline c & -6.172 & 2.028 & -3.044 & 0.012 \\
\hline
\end{tabular}

Note: $1 .{ }^{* *}, * *$ and $*$ are $1 \%, 5 \%$ and $10 \%$ of significant levels, respectively. 


\section{Conclusions and policy recommendations}

This paper reviewed selected literature on the housing market in Malaysia on several important factors. The time series were taken from the year 1988 until 2017 by annually, so there are 30 observations. All the data gathered were tested using Eviews9 and through the Autoregressive Distributed Lagged Model (ARDL) test. The model for time series data is a regression equation that is used to predict current values of a dependent variable based on both the current values of an explanatory variable and the lagged (past period) values of this explanatory variable. A diagnostic test was also run to examine whether the model is facing an econometric problem or not. In this research, the econometric problem does not arise since the model is stable.

Based on the result of this research, it can be concluded that the gross domestic product and base lending rate are significant determinants of the house price index of Malaysia in the long run. The finding shows that gross domestic product and the base lending rate have significant relationships and positive impact, and the other factors like consumer price index and the money supply were found to be not significant with house price index in Malaysia.

Based on the above empirical result, we recommend the government should control the investment activity for house commodities among foreigners because it involves speculation, which is not helping the housing market in Malaysia. Moreover, the government or private sector should provide a more low-cost house instead of a high-cost house so that people with lower or middle income can afford to buy and own houses. However, they also should make sure that the quality of the house that their product is good and safe. The household will only borrow depending on the amount of their securities' net worth.

Lastly, through the test that has been done, this research paper has achieved the research objectives that might be useful in the future even though there is a limitation to finish this project paper. Therefore, it is hoped that future research can overcome this limitation to provide a result with that accurate.

\section{References}

1. Rajasekar, S., Philominathan, P., \& Chinnathambi, V. (2006). Research methodology. Retrieved from http://arxiv.org/pdf/physics/0601009.pdf

2. Ong, T. S. (2013). Factors affecting the price of housing in Malaysia. Journal of Emerging Issues in Economics, Finance and Banking, 1(5), 414-429.

3. Lean, H. H., \& Smyth, R. (2013). Regional house prices and the ripple effect in Malaysia. Urban Studies, 50(5), 895-922.

4. Ibrahim, M. H., \& Law, S. H. (2014). House prices and bank credits in Malaysia: An aggregate and disaggregate analysis. Habitat International, 42, 111-120.

5. Sekaran, U. (2005). Research Methods for Business with SPSS 13. United Kingdom: John Wiley and Sons

6. Malaysian Investment Development Authority (MIDA). (2015). Malaysia moves up to 12 spot in global competitiveness ranking. Retrieved from http://www.mida.gov.my/home/2163/news/malaysiamoves-up-to-12-spot-in-global-competitiveness-ranking-/

7. Ong, T. S., \& Chang, Y. S. (2013). Macroeconomic determinants of Malaysian housing market. Human and Social Science Research, 1(2), 119-127.

8. Husain, F. N., Rahman, R., \& Ibrahim, N. N. (2011). Housing bubbles assessment in Klang Valley, 2005-2010. Faculty of Business Management, 4(1), 561-574.

9. Holstein, A. D., O'Roark, B., \& Lu, M. (2013). Determinants of the home price-income relationship: 1990-2011. Global Journal of Business Research, 7(3), 15-30.

10. Égert, B., \& Mihaljek, D. (2007). Determinants of house prices in Central and Eastern Europe. Comparative economic studies, 49(3), 367-388.

11. Khazanah Research Institute. (2015). Making Housing Affordable. Retrieved from http://www.http://krinstitute.org/kris_publication_Making_Housing_Affordable.

12. Suhaida, M. S., Tawil, N. M., Hamzah, N., Che-Ani, A. I., Basri, H., \& Yuzainee, M. Y. (2011). Housing affordability: A conceptual overview for house price index. Procedia Engineering, 20, 346-353. 
13. Shi, S., Jou, J. B., \& Tripe, D. (2014). Can interest rates really control house prices? Effectiveness and implications for macro-prudential policy. Journal of Banking \& Finance, 47, 15-28

14. Dougherty, A., \& Order, R. V. (1982).Inflation, Housing Costs, and the Consumer Price Index. The American Economic Review Vol. 72, No. 1 (Mar., 1982), 154-164

15. Tsai, I. C., \& Peng, C. W. (2011). Bubbles in the Taiwan housing market: The determinants and effects. Habitat International, 35(2), 379-390.

16. Tan, T. H. (2010). Base lending rate and housing prices: Their impacts on residential housing activities in Malaysia. Journal of Global Business and Economics, 1(1), 1-14.

17. Gujarati, D. N., \& Porter, D. (2009). Basic Econometrics. Mc Graw-Hill International Edition.

18. Goodhart, C., \& Hofmann, B. (2008). House prices, money, credit, and the macroeconomy. Oxford Review of Economic Policy, 24(1), 180-205.

19. Greiber, C., \& Setzer, R. (2007). Money and housing - Evidence for the Euro Area and the US. Deutsche Bundesbank Discussion Paper, Series 1: Economic, Studies, No. 12/2007

20. Zhu, H. B. (2004). What drives housing price dynamics: Cross-country evidence. BIS Quarterly Review, March

21. Aris, N. M. (2018). Empirical Analysis of Factors Influencing Residential Property Prices in Malaysia. UNIMAS Review of Accounting and Finance,1(1). doi:10.33736/uraf.1215.2018

22. Gujarati, D. N. (2012). Basic econometrics. Tata McGraw-Hill Education.

23. Choudhury, A. (2014). Lead-Lag Association of mortgage rate with housing price. Journal of Economics and Economic Education Research, 15(1), 103.

24. Tze, S. O. (2013). Factors affecting the price of housing in Malaysia. Journal of Emerging Issues in Economics, Finance and Banking (JEIEFB). An Online International Monthly Journal (ISSN: 2306 367X), 1(5).

25. Goodhart, C., Hofmann, B., \& Segoviano, M. (2004). Bank Regulation and Macroeconomic Fluctuations. Oxf Rev Econ Policy (Winter) 20(4), 591-615.

26. Pesaran, M. H., Shin, Y., \& Smith, R. J. (1996). Testing for the existence of a long-run Relationship. DAE Working Paper, No. 9622, Department of Applied Economics, University of Cambridge, Cambridge.

27. Pesaran, M. H. (1997). The role of economic theory in modelling the long run. The Economic Journal, 107(440), 178-191.

28. Pesaran, M. H., Shin, Y., \& Smith, R. J. (2001). Bounds testing approaches to the analysis of level relationships. Journal of Applied Econometric, 16, 289-326.

29. Phillips, P. C. B., \& Perron, P. (1988). Testing for unit roots in time series regression. Biometrika, 75, 335-346.

30. Phillips, P. C. B., \& Hansen, B. E. (1990), Statistical inference in instrumental variable regression with I(1) processes. Review of Economics Studies, 57, 99-125.

31. Ramsey, J. B. (1969.) Tests for specification errors in classical linear least squares regression analysis. Journal of R Statistic Society, 31(2), 350-371.

32. Rebelo, S. (1991). Long-run policy analysis and long-run growth. Journal of Political Economy, 99, $500-521$. 